\title{
Research on the Practice of Socialist Core Values in Colleges under the Background of the Communist Youth League Reform
}

\begin{abstract}
Da Luo
South China Institute of Software Engineering.cu, Guangzhou, 510990, China

Keywords: College, Students', socialist core values, problems, Countermeasures.

Abstract: College students play an important role in China's socialist construction, economic development and scientific technology innovation, and they are the driving force of China's social development and construction. However, the current values of college students show a variety of complex situations, therefore, to strengthen the consciousness of college students' socialist core values is of great significance. This paper summarizes some problems existing in the practice of socialist core values in colleges and universities in China, and proposes some countermeasures regarding these problems.
\end{abstract}

\section{Introduction}

The report of the Eighteenth National Congress of the Communist Party of China put forward that the socialist core values should be advocated and practiced, and the higher education schools, which cultivate and export talents for our country, should be the leaders in the practice of the socialist core values. College students are the future and the hope of the nation, and also the outstanding young people of modern age. With the continuous development of social economy, values have gradually formed a diversified trend of development, which has caused a serious impact on people's ideological and spiritual pursuit. Therefore, under the current social background, how to cultivate the normal values of college students and guide them to correctly practice the socialist core values is worth to think about ${ }^{[1]}$.

\section{Problems existing in the practice of socialist core values in Colleges and Universities under the background of the Communist Youth League reform}

\subsection{Specific education goals need to be improved}

The practice of College Students' socialist core values is the call of the times and historical responsibility. The socialist core values are the overall educational goals established by the state from a macro perspective, and are a mainstream of value ideology. Although the practice of socialist core values have been integrated into the whole process of national education and into the overall planning of national education, there is still a lack of stages in the educational objectives of socialist core values. For college students, it is necessary to formulate phased goals in line with the actual situation and implement them in different levels and stages ${ }^{[2]}$. If the overall goal is to guide 
college students, there may be problems such as the effect of education in the form if the implementation of work is not detailed enough, and it may cause the content of education too difficult to digest. Therefore, we should take the overall goal as the premise, combine it closely with the physical and mental development characteristics and recognize the law of modern society. Regarding the education of core values in colleges and universities, we should pay attention to the combination of ideas and practice, change the management mechanism, pay attention to flexible management, and pay attention to the guarantee of policies and the standardization of systems. Only in this way can we achieve the best educational effect.

\subsection{The trend of socialist belief is weakening.}

The gradual weakening of socialist beliefs is a prominent manifestation of cultivating and practicing the core values of socialism in Colleges and universities. College students are in an important period of life development. Their minds are not yet mature, and their thoughts are easy to develop and change with the changes of external factors. In the face of various crises, some students often fall into depression. Over time, they lose their recognition of socialist beliefs, lose their self-identity, show obvious utilitarianism and pursue the value of nothingness ${ }^{[3]}$. The main manifestation is that although the life is rich, the spirit is gradually becoming empty. Although some people is full of confidence in the development of the country, but in the face of social problems such as power trading, corruption and injustice in the real society are worth to worry, and even some students because of incitement and embarked on the wrong road, thus affecting the university owners of society.

\subsection{Diversification of values}

Influenced by the secularization and utilitarianism of the market economy, the values of college students are changing day by day, and the values are becoming vague and tend to be beneficial. Some students only pay attention to the satisfaction of sensory enjoyment and personal immediate interests, when the national and personal interests conflict, often unwilling to sacrifice their own interests. It is mainly focusing on the high expectation of work, the desire to enjoy superior material life and the pursuit of rich spiritual connotations. People are unwilling to work in remote and difficult poverty-stricken areas or grass-roots units, the idea and behavior are dominated by their own interests, recognition and pursuit of some western bad life concepts and ways, the pursuit of vulgarity and harmony. Fast food culture ignores the objective laws of human history. Detailed socialist core values shown as below figure 1 .

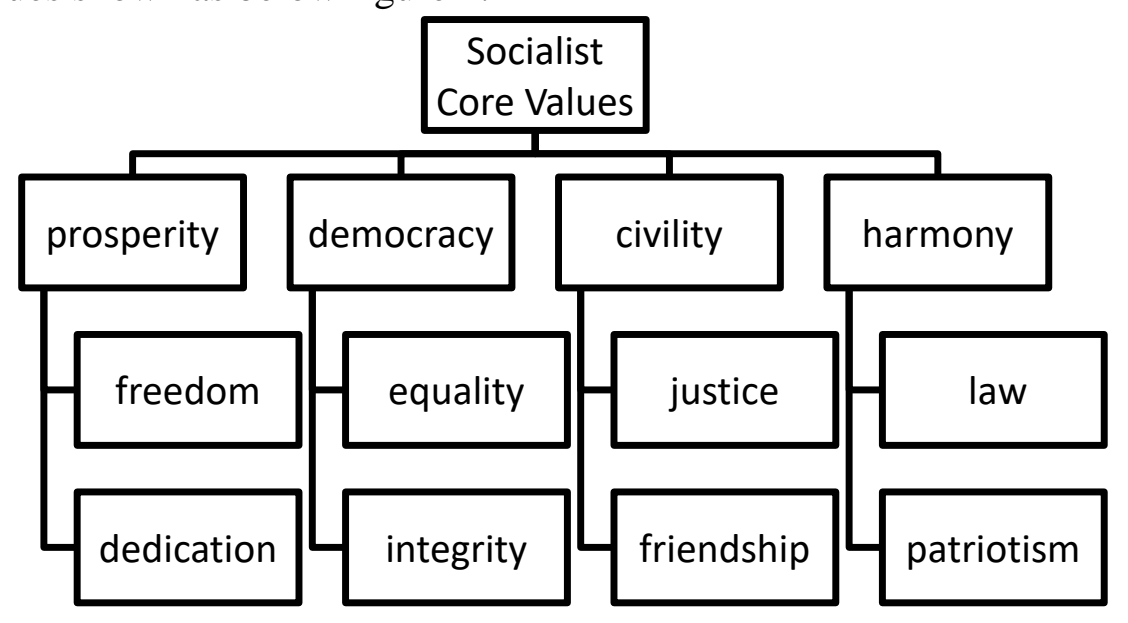

Figure 1 Socialist Core Values 


\section{Effective countermeasures for solving the problems of socialist core values in Colleges and Universities under the background of the reform of the Communist Youth League}

\subsection{The goal of education should adhere to the ladder principle.}

In the process of cultivating and practice socialist core values in colleges and universities, we should combine the overall goal with the specific goal and combine the students' common cognition with the special cognition. Besides adhering to the principle of goal stage, people should also pay attention to integrating the students' socialist core values into daily life, paying attention to details and not being merged into daily life form specific methods such as, the leadership of colleges and universities to establish and improve the ladder education responsibility system, responsibility to people, phased, hierarchical goal. In the process of ladder education, the incentive mechanism should best strengthened, and the educational effect of the goal should be taken as an important index of cadre assessment. In addition, we should implement the safeguard mechanism of the principle of ladder education, and provide necessary safeguards in terms of funds, personnel and information technology methods ${ }^{[4]}$.

\subsection{To carry forward the national spirit and the spirit of the times}

Some students lack the sense of national pride, deny the traditional Chinese moral values, show the values of national nihilism and egoism, lack self-confidence, lack spiritual pursuit, do not care about the development and progress of society, and blindly pursue hedonism, hedonism and things. Materialism. This is also an important factor affecting the generation of correct socialist core values of college students. Therefore, we must attach importance to the pursuit of these students' national spirit and the spirit of the times. The national spirit and the spirit of the times are important banners to encourage the people to strive for strength, and are the motive force to ensure a nation's endless life. In order to solve the problems existing in the practice of socialist core values in colleges and universities, we must vigorously publicize and carry forward the national spirit and the spirit of the times of the Chinese nation, change the bad ideas of college students, promote their concern for the national strength and social development, keep pace with the times and finally constantly strive for self-improvement ${ }^{[3]}$.

\subsection{Correctly guide and make full use of the positive energy of the network}

Network is a double-edged sword. It can not only help colleges and universities to practice the socialist core values, but also bring some negative impact on college Students' ideological education. The information discrimination ability of college students is usually weak, and they are easily disturbed by bad information from the outside world. At present, the cultural traditions, ideological concepts, religious beliefs of different countries and nationalities are not uniform, and even some extreme ideas are spread, which has a certain impact on the formation of college students' values. Hit. Therefore, we must attach importance to training students to correctly understand the media information, improve their ability to distinguish between true and false, consciously resist obsolete, bad, decadent, backward false information. Colleges and universities can create a column on the education of socialist core values by establishing a "student portal website" in which the relevant content of socialist core values can be incorporated. At the same time, we should strengthen the supervision of campus network, shield the grey website, purify the campus network environment, give full play to the convenience of the network for college students, and guide them to practice the socialist core values. 


\section{Conclusion}

To enhance the ideological position construction in colleges and universities is a systematic and arduous task but it is also a necessary precondition for the implementation of socialist core values. Only by doing practical things steadfastly, students can get well learned about actual educational function of socialist universities.

\section{References}

[1] Cui Jingyu. The Communist Youth League leads the research on cultivating and practicing the socialist core values of college students [D]. Shanxi Normal University, 2017.

[2] Song Wei. Study on the integration of socialist core values into the construction of campus culture [D]. Zhengzhou University, 2016.

[3] Wang Lulu. Study on the values of contemporary college students in China from the perspective of cultural ecology [D]. Shandong University, 2016.

[4] Zheng Meng Meng. Research on the dissemination of socialist core values based on new media [D]. Soochow University, 2016.

[5] Hu Dong. Research on the education innovation of contemporary college students' life values [D]. Huazhong Normal University, 2015. 